\title{
羽田空港の容量拡大による 航空輸送の生産性への寄与とその経済効果
}

\author{
石倉 智樹 $1 \cdot$ 土谷 和之 2 \\ 1正会員 国土交通省 国土技術政策総合研究所（テ239-0826 神奈川県横須賀市長瀬 3-1-1） \\ E-mail: ishikura-t92y2@ysk.nilim.go.jp \\ 2正会員 株式会社 三菱総合研究所（干100-8141 東京都千代田区大手町2-3-6) \\ E-mail: kazuyuki@mri.co.jp
}

\begin{abstract}
本研究は, 空港容量の拡大が我が国の航空輸送サービス産業の生産効率性に寄与してきた効果を, 全要 素生産性アプローチにより推定し，応用一般均衡モデルとの結合により，その国民経済的効果についても 推定する手法を提案する. さらに本研究は, 本手法を羽田空港を事例に適用し, これまでの発着容量拡大 がもたらしてきた経済効果を推定するとともに，再拡張によってもたらされる経済効果についても試算を 行った.
\end{abstract}

Key Words : airport development, productivity, computable general equilibrium model, Haneda Airport

\section{1.はじめに}

航空輸送サービス産業の生産活動において，空港とい う社会資本が不可欠である以上，空港容量が逼迫しボト ルネック化することによって，生産効率性が低下寸るこ とは不可避である．特にネットワークの中核をなす空港 における容量制約は，効率的に生産量拡大が可能な地点 における物理的な生産量制約となり，航空輸送サービス 産業の成長を阻害する主要因となる，したがって，その ような空港における容量に余裕を持つこと自体が，経済 学的な意味での生産効率性の向上をもたらすと言えよう.

我が国の国内航空輸送ネットワークの中心的空港は, 東京国際空港 (以下, 羽田空港と呼ぶ) である. したが って, 羽田空港の容量拡大が, 航空輸送サービス産業の 生産性一寄与寸る度合は大きいと考えられる。

また，航空輸送サービスは，様々な産業の生産活動に おいて派生需要として中間投入的に利用されるため, こ の生産性の向上の効果は航空輸送サービス産業のみなら ず，あらゆる産業の経済活動に波及すると考えられる。 その結果，国民経済レベルでの大きな効果が生じると期 待される.

一般に用いられる（部分均衡的な）費用便益分析の手 法や産業連関分析による経済効果手法では，事前に with/withoutそれぞれのケースについて航空需要予測值を 推定することが必要となる. このため, 需要予測值が得
られていなければ，経済効果計測を行うことができない という問題点を抱えている. したがって, 航空需要予測 值の有無に依存せず, 空港整備による経済効果を直接推 定する手法が望まれる.

そこで, 本研究は, 羽田空港の容量拡大による航空輸 送サービスの生産性向上，およびその経済波及効果・便 益を, 需要予測值の有無に依存せず, 評価する手法を構 築する。 さらに本研究は, 羽田空港の整備が我が国経済 に及ぼしてきた効果，再拡張事業等による将来の容量拡 大がもたらす効果について, 特に航空輸送サービス産業 の中間投入構造等を通じた他産業へ及ぶ効果に着目し， 試算を行う.

\section{2. 空港の生産性と空港整備による経済効果に関 する既存研究}

1980年代後半より蓄積されてきた社会資本の生産性を 扱った研究1) は, 国民経済レベルのようなマクロな経済 に対して，集計的（空港や道路など，種別を問わないと いう意味において）な社会資本整備が寄与してきた効果 を対象とするものが多い. 我が国における代表的な研究 としては三井・太田2)によるものなどが挙げられる。こ

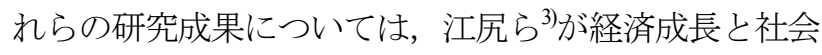
資本生産性の関連という観点から研究成果のレビューを 行っている. 
こうしたアプローチは，公共投資全体のマクロ経済的 効果を評価する際には有効である。しかし，社会資本整 備の意思決定は，個別社会資本毎に行われるものであり， その効果をより詳細に把握する必要がある.

対象となる社会資本を限定して生産性計測を行ったも のとしては, 例えば木村 ${ }^{4}$ がトラック輸送業と内航海運 業について，規制緩和による生産性への影響を分析した。 木村 ${ }^{4}$ は，各産業部門において規制緩和のタイミングを 考慮した, 時点間毎のTFP（全要素生産性）変化を計測 し，規制緩和によるTFP変化一の影響を考察した。また， 中島 ${ }^{5}$ は，同様にTFP計測アプローチにより，我が国の 鉄道事業における生産性変化を分析している.

この両者はいずれも, TFP変化の時点間比較から, 生 産性一の影響要因を分析しており, 外生要因によるTFP 変化一の寄与度合を定量的に評価したものではない，本 研究のように, 生産性変化の推定自体が目的ではなく, 社会資本整備による生産性変化を通じた経済効果推定を 目的とする場合，外生的な社会資本整備水準指標と生産 性変化の関係を定量的に把握する必要がある.

本研究がテーマとする空港に関しては, 空港単体の生 産性について, Gillen and Lall ${ }^{\natural} に$ 代表されるDEA(Data Envelopment Analysis)手法や, Hooper and Hensher ${ }^{7} に$ に代表さ れるTFP手法に関する研究が多数蓄積されている. 実証 的適用事例として，世界各国の空港間における生産性比 較8も行われている.

こうした研究は，空港毎のパフォーマンスを計測する ことを目的としており, Forsyth" によるレビューが詳し い. しかし, これらの研究は, 空港自体の生産性計測を 扱っているが，空港のパフォーマンス向上が航空輸送サ ービス産業に及ぼす効果については言及していない。

任意の産業部門における技術的インパクトによる他産 業への経済波及効果を分析するには，応用一般均衡モデ ル（以下，CGEモデル）が有用である. 航空輸送サービ 又産業部門からの経済波及効果を分析した研究としては, Ueda et al. ${ }^{10)}$ や筆者らによる先行研究11)などが挙げられる. Ueda et al. ${ }^{10)}$ は, 多地域を明示的に扱ったSCGEモデルを 用いて, 羽田空港再拡張による地域間便益帰着分析を行 った．筆者ら ${ }^{11} は$ ，我が国の航空輸送サービス産業の生 産性向上がもたらす国民経済的効果と航空および鉄道需 要へのインパクトを分析した. これらはいずれも, 航空 輸送サービス産業の技術変化を外生としており, 空港整 備事業や容量拡大と航空輸送サービス産業の技術との関 係はモデル化されていない.

本研究は, 空港の容量拡大と生産性向上の関係をモデ ル化し，これをCGEモデルと結合することにより，容量 拡大による技術変化と，その経済波及効果との関連を明 確化している.

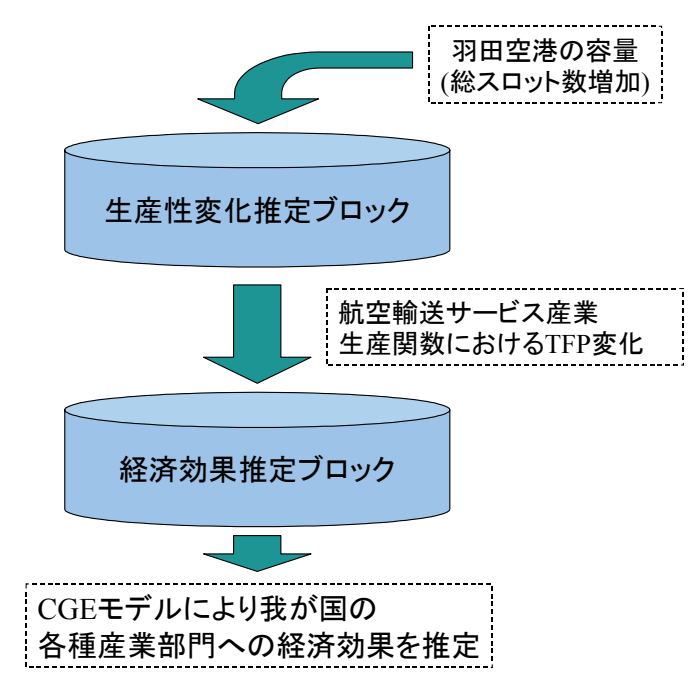

図-1 モデルの全体的枠組み

\section{3. モデルの全体的枠組み}

本モデルは，航空輸送サービス産業の生産性変化を推 定するブロックと, その生産性変化を入力值として経済 効果を推定するブロックの組み合わせにより構成される (図-1).

生産性変化推定のブロックは, 我が国の航空輸送サ一 ビス産業について, 生産関数アプローチを用いて, 羽田 空港の総スロット数と, Hicks中立型Solow残差として定 義した同産業のTFPとの関係をモデル化し, 羽田空港の 容量拡大がTFP向上に及ぼす効果を推定する. 具体的に は, 羽田空港の総スロット数変化を航空輸送サービス産 業におけるTFPパラメータの変化へと変換する役割を果 たす。

経済効果推定のブロックでは, 航空輸送サービス産業 のTFP変化を先決入力值として外生的に与え, CGEモデ ルにより我が国経済の各産業へ及ぼされる経済効果が推 定される. 本モデルでは最終的に,CGEモデルにより各 種産業部門における生産額変化を, 経済効果として計測 する.

\section{4. 羽田空港の容量拡大による航空輸送サービス 産業の生産技術への影響}

\section{（1）航空輸送サービス産業の生産関数の推定}

本章は, 生産関数アプローチを用いて, 羽田空港の発 着容量を生産性寄与要因として取り込んだ航空輸送サー ビス産業の生産関数をモデル化し, 羽田空港の容量拡大 
が航空輸送サービス産業の生産性に与えてきた効果を推 計する.

航空輸送サービス産業の生産関数を, 以下のように定 式化する.

$$
\begin{aligned}
& Y_{m t}=A_{t} \cdot f_{Y}\left(K_{m t}, L_{m t}, I_{m t}\right) \\
& A_{t}=f_{A}\left(\mathbf{E}_{t}\right)
\end{aligned}
$$

$Y_{m t}$ : 時点 $\mathrm{t}$ での航空輸送サービス産業 $\mathrm{m} の$ 生産量

$K_{m t}$ : 時点 $\mathrm{t}$ での航空輸送サービス産業 $\mathrm{m} の$ 資本投入

$L_{m t}$ : 時点 $\mathrm{t}$ での航空輸送サービス産業mの労働投入

$I_{m t} \quad$ : 時点 $\mathrm{t}$ での航空輸送サービス産業 $\mathrm{m} の$ 中間投入

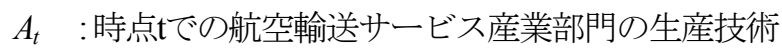

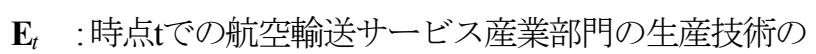
シフト要因変数ベクトル

すなわち, 航空輸送サービス産業は, 本源的生産要素 である資本と労働および中間財を投入し，航空輸送サ一 ビスの生産を行うと仮定される. 各時点の各航空輸送サ 一ビス産業の生産技術（全要素生産性: TFP）は，これ をシフトさせる外的要因によって変化する.

羽田空港における近年の総スロット数と発着回数実績 を比較すると（図-2），容量はほぼ一杯に利用されてい る状況が継続している. したがって，羽田空港における 総スロット数の制約が, 航空輸送サービス産業の生産活 動におけるボトルネックとなっていた可能性がある。こ のため, 総スロット数制約の緩和により，新たな市場拡 大の機会増大等による, 生産効率性の向上がもたらされ てきた可能性もあると考えられる.

本研究は羽田空港の容量拡大による, 航空輸送サービ ス産業の生産性への要因に着目するため, 羽田空港の総 スロット数を生産技術のシフト要因変数として採用する. 関数形については，次章のCGEモデルとの整合性を鑑み， 以下のように，全投入に対して一次同次性をもつCobbDouglas型関数を仮定した.

$$
\begin{aligned}
& Y_{m t}=A_{t} \cdot K_{m t}^{\beta_{2}} L_{m t}^{\beta_{3}} I_{m t}^{\beta_{4}} \\
& \beta_{4}=1-\beta_{2}-\beta_{3}
\end{aligned}
$$

$$
\beta_{2}, \beta_{3}, \beta_{4}: \text { パラメータ }
$$

パラメータ推定のために用いたデータ，およびデータ 加工方法について表-1に示す. 航空産業のデータとして は，我が国の大手エアライン3社である，日本航空(JAL), 全日本空輸(ANA), 日本エアシステム(当時, JAS)を対象 とした。これら以外の小規模エアラインについては，使
用機材の構成が異なることや，地域的サービスに特化し ていることなどの理由から生産構造が大きく異なる可能 性を考慮し，データの対象としなかった。

なお，各々のデータについて，1985年度から2001年度 までの17年間の時系列データを用いた。このことは, 2002年におけるJALとJASの経営統合により，財務デー タに，生産構造と独立な攪乱が生じている可能性を考慮 したためである。

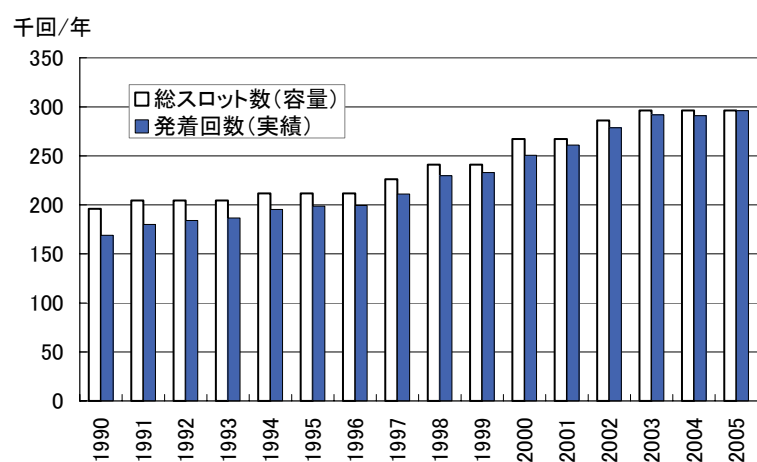

※総スロット数は 6:00〜8:30 の到着，20:30～23:00 の出発お よび 23:00〜 6:00 の発着を除く「利便時間帯の発着可能回

\begin{tabular}{|c|c|c|}
\hline データ項目 & 出典 & データ加工方法 \\
\hline $\begin{array}{l}\text { 航空輸送企業 } \\
\text { 別生産量 } \\
\text { (平成 } 7 \text { 年暦 } \\
\text { 年価格) }\end{array}$ & $\begin{array}{c}\text { 航空統計要覽 } \\
\text { (2003 年版) }\end{array}$ & $\begin{array}{l}\text { JAL, JAS, ANA の営業 } \\
\text { 収益を国内総支出デ } \\
\text { フレータでデフレー } \\
\text { トし実質化 }\end{array}$ \\
\hline $\begin{array}{l}\text { 羽田空港 } \\
\text { 総スロット }\end{array}$ & 航空局資 & \\
\hline $\begin{array}{l}\text { 航空輸送企業 } \\
\text { 別中間投入 } \\
\text { (平成 } 7 \text { 年暦 } \\
\text { 年価格) }\end{array}$ & $\begin{array}{l}\text { 航空 統計 要 覧 } \\
\text { (2003 年版) } \\
\text { 各企業の有価証 } \\
\text { 券報告書 }\end{array}$ & $\begin{array}{l}\text { 中間投入 =航空燃油 } \\
\text { 費+整備費+運航施 } \\
\text { 設利用費十販売費一 } \\
\text { 般管理 }+ \text { 代理店手数 } \\
\text { 料十航空保険費 }+ \text { そ } \\
\text { の他 } \\
\text { (販管費中の減価償 } \\
\text { 却費は除く) }\end{array}$ \\
\hline $\begin{array}{l}\text { 航空輸送企業 } \\
\text { 別資本投入 } \\
\text { (平成 } 7 \text { 年暦 } \\
\text { 年価格) }\end{array}$ & $\begin{array}{l}\text { 航空統計要覽 } \\
\text { (2003 年版) } \\
\text { 各企業の有価証 } \\
\text { 券報告書 }\end{array}$ & $\begin{array}{l}\text { 資本投入=営業利益 } \\
\text { 十航空機材減価償却 } \\
\text { 費十販売費一般管理 } \\
\text { 中の減価償却費 }\end{array}$ \\
\hline $\begin{array}{l}\text { 航空輸送企業 } \\
\text { 別労働投入 } \\
\text { (平成 } 7 \text { 年暦 } \\
\text { 年価格) }\end{array}$ & $\begin{array}{l}\text { 航空統計要覧 } \\
\text { (2003 年版) } \\
\text { 各企業の有価証 } \\
\text { 券報告書 }\end{array}$ & 労働投入 $=$ 人件費 \\
\hline
\end{tabular}
数」である

\section{資料：国土交通省資料}

図-2 羽田空港の総スロット数と発着回数

表-1 パラメータ推定に用いたデータ 
交通企業の生産関数を推定する場合，生産量を表す指 数として旅客数・輸送人キロのような物理量を適用する ケースと，収益のような金額值を適用するケースの両方 が考えられる. 本研究は, 後述するCGEモデルとの整合 性を鑑み, 額ベースの営業収益を生産額すなわち生産量 と見なす．資本投入，労㗢投入についても同様に額べー スの值を用いることとした.

生産技術を表す関数の特定化においては，関数形やそ の他シフト要因について, 種々のパターンを検討した結 果, 最も当てはまりの良かった次の関数を用いた.

$$
A_{t}=\exp \left(\beta_{0}\right) \exp \left(\beta_{11} \cdot \text { Trend }_{t}\right) \exp \left(\beta_{12} \cdot D_{\text {haba }}\right) \cdot E_{t}^{\beta_{13}}
$$

Trend $_{t}$ : トレンド要因変数

$D_{\text {haba }} \quad$ : 幅運賃制ダミー（1996年以降に1をとる）

$E_{t} \quad$ : 時点礼おける羽田空港の総スロット数

$$
\beta_{0}, \beta_{11}, \beta_{12}, \beta_{13} \text { :パラメータ }
$$

パラメータ推定の結果を表-2に示す，パラメータの推 定においては，式(4)を式(2)一代入し，さらに対数線形 変換することにより，全パラメータを同時に推定した.

表-2より, 羽田空港の総スロット数に関するパラメー 夕 $\left(\beta_{13}\right)$ における值が，有意でない（有意水準は12.8\%) 結果となっている. しかし，空港は航空輸送サービスの 生産に不可欠な社会資本であり, 特に, 我が国の航空市 ットワークの中心である羽田空港の容量はその生産技術 に影響すると考えられるので, 有効な説明変数と見なす こととする.

同様に幅運賃制ダミーに関するパラメータ $\left(\beta_{12}\right)$ につ いても埴が低い（有意水準は22.7\%）ものの，価格規制 の緩和という航空市場環境に大きなインパクトを持つ要 因であるため，説明変数として採用寸ることとした．推 定結果より，幅運賃制の導入により生産性に正の効果を もたらした可能性があると解釈することができる.

表-2 生産関数パラメータ推定結果

\begin{tabular}{|cccc|}
\hline 変数 & パラメータ & 係数 & $\mathrm{t}$ 值 \\
\hline 定数項 & $\beta_{0}$ & 0.1276 & 0.29 \\
Trend $_{t}$ & $\beta_{11}$ & -0.0055 & -1.89 \\
$D_{h a b a}$ & $\beta_{12}$ & 0.0109 & 1.23 \\
$E_{t}$ & $\beta_{13}$ & 0.1123 & 1.55 \\
$K_{m t}$ & $\beta_{2}$ & 0.0697 & 15.32 \\
$L_{m t}$ & $\beta_{3}$ & 0.2318 & 12.87 \\
\hline 自由度調整済み決定係数 & & 0.966 \\
\hline
\end{tabular}

トレンド要因がマイナスに効く結果となっているが, これは1985年以降の航空規制緩和などによる市場環境变 化に伴い，イールドが低下し航空産業の収益性が低下し たことを反映していると考えられる.

この生産関数を利用し，1985年から2001年までの羽田 空港発着枠拡大によってもたらされた生産性向上率を推 定すると，7.6\%という值が得られた。

\section{5. 応用一般均衡（CGE）モデルを用いた羽田 空港容量拡大による経済効果の分析}

\section{（1）モデルの概要と前提条件}

本章は，前節で推定結果した航空輸送サービス産業の 生産関数を取り込んだCGEモデルを構築し，空港施設整 備による直接的な効果（航空輸送サービス産業の生産性 向上等）のみならず波及的な効果まで含めた計測を行う。 モデルの前提条件を以下のように設定する.

・日本国経済を1地域経済と見なす。

・経済主体は家計と企業の2主体より構成されている. 政府部門については，国内における所得再配分主体であ るが，家計部門を一主体として扱っているため分離して 考慮する必要性が小さく, 本モデルでは明示的に考慮し ない.

・簡単化のため, 国内最終需要は全て家計消費と見なす. 貯蓄投資バランスに関しては，投資需要を明示化しない ため, 要素所得のうち, 国内消費に利用されない部分を 貯蓄として見なし, 純輸出額 (経常収支黒字) とバラン ス寸ることとする.

・全ての市場が完全競争状態であり，生産活動について は各産業（アクティビティベース）毎に集計的企業の生 産関数として表す.

・社会は長期的均衡状態にある.

・家計は生産要素（労働・資本）を保有し，企業にこれ らを提供し対価として所得を受け取り，財・サービスの 消費により効用を最大化する.

- 企業は, 中間投入財と, 家計から提供される労働・資 本を生産要素として投入することにより, 財・サービス を生産し，利潤を最大化する。

CGEモデルの基準均衡データとして，2000年産業連関 表32部門表を用いた．ただし，航空輸送サービス産業に 着目した分析にあたり，32部門表では運輸業が細分化さ れていないため，104部門表のデータを用いて「航空輸 送」部門と「その他運輸業」部門を分離した。

なお，32部門表においては「鉱業」部門と「石油・石 炭製品」部門は区分されているが，「鉱業」部門の国内 最終需要がマイナスである.このため「鉱業」部門を区 
分した状態では, 適切な効用関数パラメータの推計を行 うことができない．このため，本研究は，産業部門分類 の設定にあたり，「鉱業」部門と「石油・石炭製品」部 門を統合した.「鉄鋼」部門についても同様に国内最終 需要がマイナスであるため，「非鉄金属」部門と「金属 製品」部門を統合した.

\section{（2）モデルの定式化}

\section{a) 家計の行動}

家計は，労働・資本を企業に提供し，それにより得ら れる所得を用いて財・サービスを消費する. 効用関数は, 以下のようにCobb-Douglas型関数として定式化する.

$$
\begin{array}{ll}
\max _{x_{i}} & U=\prod_{i}\left(d_{i}\right)^{\beta_{i}} \\
\text { s.t. } & \sum_{i} p_{i} d_{i} \leq w L+r K-S
\end{array}
$$

$$
\begin{aligned}
U & : \text { :家計の効用 } \\
d_{i} & : \text { 家計の財・サービス需要量 } \\
p_{i} & : \text { 財・サービス価格 } \\
w & : \text { 賃金率 } \\
L & : \text { :家計の労働初期保有量 } \\
r & : \text { 資本レント } \\
K & : \text { :家計の資本初期保有量 } \\
S & \text { :貯蓄 }(\text { 要素所得における消費の残余) } \\
\beta_{i} & : \text { :シェアパラメータ }\left(\sum_{i} \beta_{i}=1\right)
\end{aligned}
$$

上記の効用最大化問題より, 最終需要の需要関数を導 出することができる.

\section{b）企業の行動}

企業は中間投入および労働・資本を用いて生産活動を 行い，利潤を最大化する．生産関数についてもCobbDouglas型で定式化する.これは，中間投入財同士や資 本・労働の間での代替を許す定式化であり, 長期的には 財・サービス価格や資本価格，労働価格の変化により生 産構造が変わることを想定した定式化である.

最適投入計画の基淮として，以下の費用最小化問題を 考える. この問題を解くことにより, 中間投入財および 生産要素についての派生需要関数を導出寸ることができ る.

$$
\begin{aligned}
& \min _{x_{i j}, K_{j}, L_{j}} \sum_{i} p_{i} x_{i j}+r K_{j}+w L_{j} \\
& \text { s.t. } x_{j}=\eta_{j} \prod_{i}\left(x_{i j}\right)^{\alpha_{i j}} \cdot K_{j}^{\alpha_{k j}} \cdot L_{j}^{\alpha_{L j}}
\end{aligned}
$$

$x_{j}:$ 産業jの産出量

$x_{i j}$ : 産業艿が産業iから投入する中間投入財の量 $K_{j}:$ 産業手の資本需要量
$L_{j}:$ 産業jの労働需要量

$\alpha_{i j}, \alpha_{K j}, \alpha_{L j}:$ シェアパラメータ

$\left(\sum_{i} \alpha_{i j}+\alpha_{K j}+\alpha_{L j}=1\right)$

$\eta_{j}:$ 生産技術パラメータ

シェアパラメータと生産技術パラメータについて，産業 連関表からの読みとり方法は，付録に示寸．

\section{c）モデルの閉じ方と均衡条件}

海外部門の閉じ方については，簡単化のために純輸出 量を外生変数と見なす.

$$
\sum_{i} p_{i} N E_{i}=N X
$$

$$
S=N X
$$

$N X:$ 経常収支黒字

$N E_{i}$ : 財・サービスの純輸出量 (外生)

本研究の分析対象は羽田空港の容量拡大による経済効 果であり，国民経済というマクロなレベルにおいて，国 内財と海外財との代替関係のような貿易構造に及ぶ影響 は小さいと考えられる，そこで本研究では，中間投入に おいても最終需要においても国内財と輸入財を無差別に 扱い，産業連関表に表れる需要を全て国内財需要と見な した.

財・サービスおよび要素市場における均衡条件は以下 のように表される.

$$
\begin{gathered}
x_{i}=\sum_{j} x_{i j}+d_{i}+N E_{i} \\
K=\sum_{j} K_{j} \\
L=\sum_{j} L_{j}
\end{gathered}
$$

各市場において，これらの均衡条件を満たすように価 格が調整され，全ての市場を清算する価格ベクトルが均 衡解となる.

\section{（3）羽田空港の発着容量拡大によってもたらされる国民 経済効果の分析}

前章で推計した生産関数によると，1985年から2001年 までの羽田空港の発着容量拡大による航空輸送サービス 産業の全要素生産性の変化は約7.6\%である. なお，この 值は, 生産技術変化のうち, 羽田空港の発着容量拡大の みの寄与によるものと解釈され，研究開発等による技術 
変化は含まれない.したがって，これをCGEモデルにお ける航空輸送サービス産業の生産関数に入力することに よって，当該期間における羽田空港の発着容量拡大によ る国民経済的な効果を, 容量拡大以外の要因と分離して 計測することが可能である.

生産関数のパラメータを特定するために, 前章ではエ アラインの財務データを用いているが本章では産業連関 表を基にしている. こうした相違点のために，前章と本 章の生産関数では, 厳密にはパラメータの不整合が生じ ている.

しかし，本章の分析では航空輸送サービス産業のTFP 変化のみを利用している。したがって，投入財および投 入要素の代替関係不整合の影響は回避される. これらの 不整合に伴う，両モデルの接合に関する理論的問題につ いては, さらに検討が必要だが, 今後の課題としたい.

分析の手順として, 具体的には, 航空輸送サービス産 業の生産関数の生産技術パラメータ $\eta_{j}$ を1.076倍したケ 一スをwith, $\eta_{j}$ を変化させないケースをwithoutとして, その差の比較を行った. 寸なわち，1985年から2001年の 間に，一切の羽田空港容量増加がなく，1985年時点の空 港容量を想定した場合（without）と，実際の空港容量の 場合（with）のそれぞれについて均衡状態を計算し，そ の差を，この期間における空港容量増加による経済効果 として計測する.
航空輸送サービス産業の生産性向上による財・サービ スの価格低下率と, 各産業における航空輸送の投入係数 の比較を図-3に示寸（ただし，航空輸送は除く）。図-3 から分かるように，航空輸送の投入係数が比較的高い産 業（商業，通信・放送，その他の公共サービスなど）に おける財・サービスの価格低下率が大きいことがわかる。

一方, 航空輸送の投入係数が低い農林水産業や食料品 などにおいても，投入係数が高い産業の $1 / 2$ 程度の価格 低下率を示しており, 航空輸送サービス産業の生産性向 上が産業間の取引を通じて幅広い産業に影響を与えるこ とが示唆される.なお，航空輸送は約 $4.63 \%$ 価格が低下 するといら結果が得られた.

同様に，生産額の変化を図-4に示す（ただし，航空輸 送は除く）。これも商業, 対事業所サービスのような航 空輸送からの投入が比較的大きい産業における伸びが大 きい. 鉱業・石油・石炭製品部門において変化率が大き いことは, 航空輸送の中間投入として航空燃油の需要が 大きく増加したことに起因すると考えられる，なお，航 空輸送の生産額の増分は約1,464億円/年となり，産業全 体での生産額増分は約2,418億円/年となる.

なお, $\mathrm{EV}$ (等価変分) により家計に帰着する便益を 計測すると, 約1,140億円という結果が得られた.

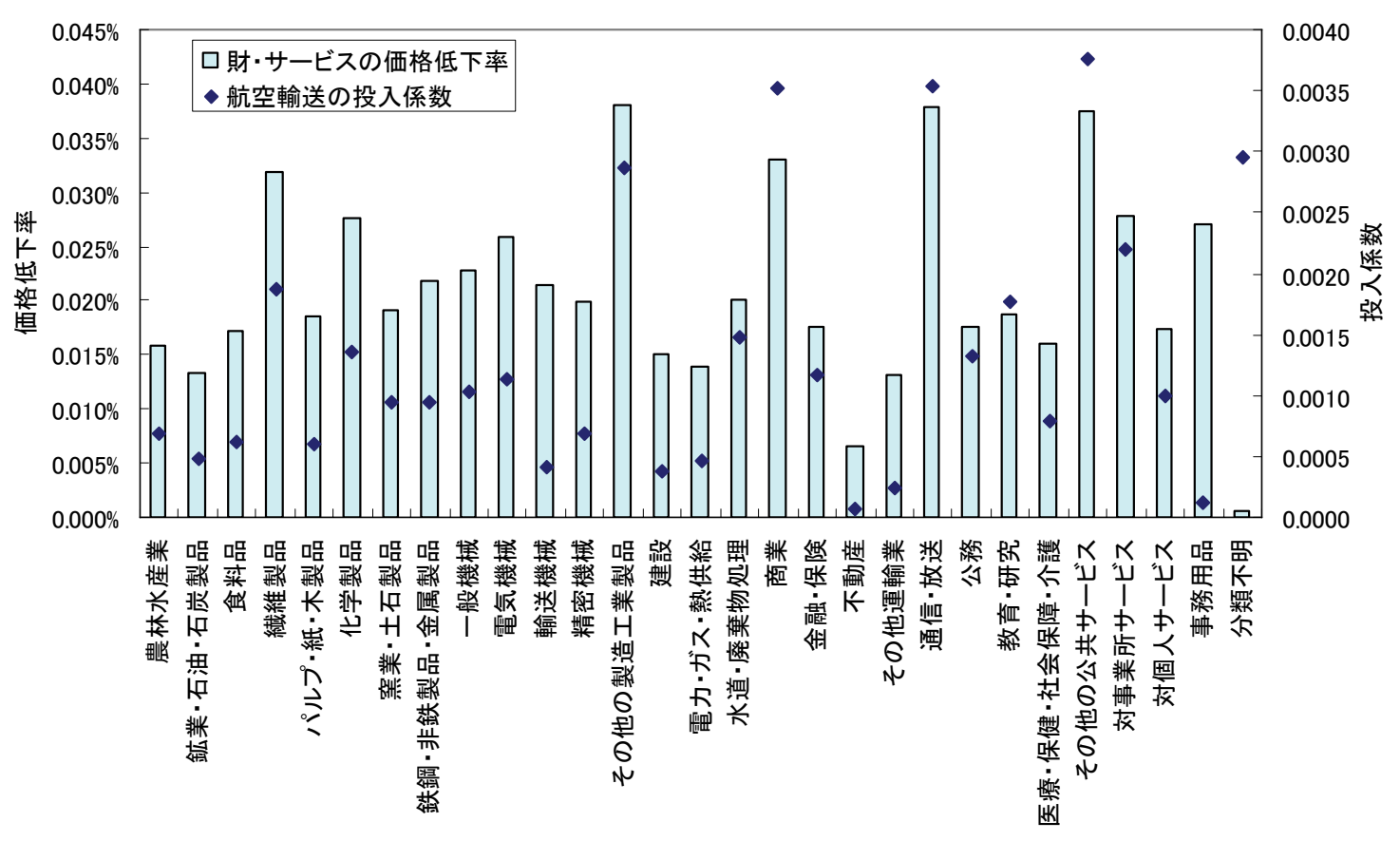

図-3 財・サービスの価格変化および投入係数 


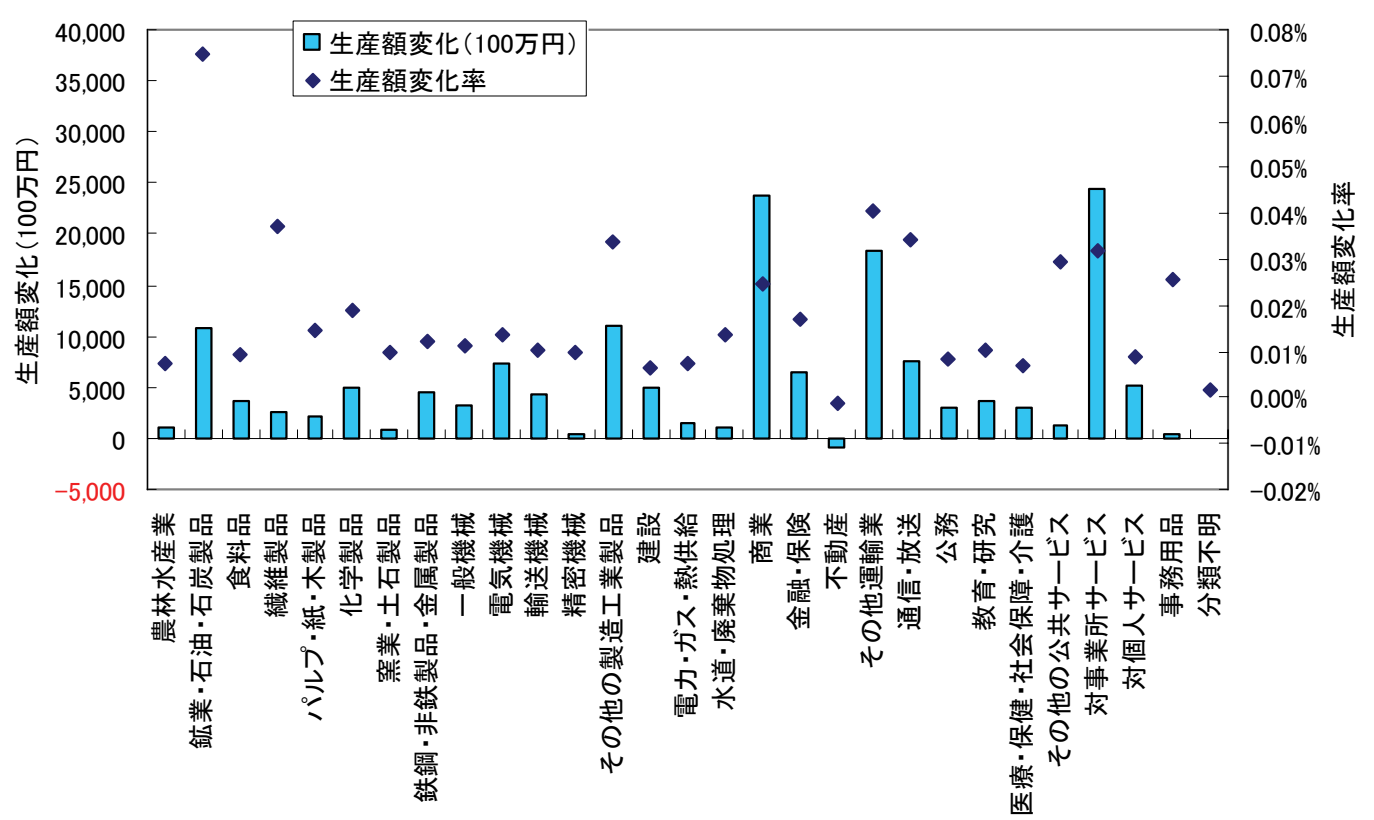

図-4 生産額の変化

（4）羽田空港再拡張がもたらす生産性向上およびその経 済効果

現在, 羽田空港においては再拡張事業が進められてお り, 将来には容量拡大が実現する. 羽田空港の容量増加 は, 首都圈における航空輸送ネットワークのボトルネッ クを緩和し，航空輸送サービスの生産性向上をもたらす ことが期待される．そこで本節は，構築したモデルを用 いて, 羽田空港再拡張による総スロット数増加がもたら 寸生産性向上，およびその結果として生じる経済効果に ついて分析を行う。

なお，羽田空港再拡張事業に関しては，費用対効果分 析（平成16年3月新規事業採択時評価の対象）および経 済波及効果分析 ${ }^{12)}$ の結果が既に公表されている.

前者は, 航空需要予測の推定值を入力值として, 部分 均衡分析アプローチにより便益を推定したものであり, 航空需要予測值の精度が高い点, 発生ベースで計測され た便益の推計精度が高い点などの長所を持つ. 後者は, 再拡張事業により生じる経済的な直接効果を推計し，さ らに産業連関分析アプローチにより間接波及効果も推計 するものであり, 特に直接効果について, 航空券売上や 交通アクセス消費額など，詳細に把握できるという利点 がある. また, 両者に共通する点として, 羽田空港の容 量制約をwith-without比較分析において明示的に扱ってお り，ボトルネック解消による経済効果を評価していると いう特徵がある。

これに対して本研究は, 羽田空港の総スロット数増加
を航空輸送サービス産業の生産関数シフト要因, 寸なわ ち技術変化と捉え, 市場メカニズムを通じた価格体系の 変化によりあらゆる経済効果を分析する一般均衡分析ア プローチを採用している．したがって，国民経済レベル での需給均衡から航空需要が推定されるため, 前述の既 存分析と比べ, 航空需要の精度が粗くなることは避けら れない. したがって, 結果として算出される航空需要や 便益の值自体を推定するためには，既存手法のほうが合 目的である. しかし本手法は，前述の既存手法では考慮 されていない, 航空輸送サービス産業以外の市場をも明 示的に扱っており, 価格体系の変化や他産業部門に及ぶ 影響の分析においては優れている.

分析にあたり，前提条件として，国土交通省航空局 ${ }^{22}$ と同椂に, 羽田空港再拡張により総スロット数が 40.7 万 回に増加した状況を設定する. 式(4)および表-1のパラメ ータを用いて, 航空輸送サービス産業のTFP向上を推定 すると, 羽田空港の再拡張による容量拡大によって, 2000年現在からTFPが4.8\%向上するという結果が得られ た.

この值を, CGEモデルにおいて, 航空輸送サービス産 業の生産関数（式(6)）における $\eta_{j}$ の変化として扱い, 種々の経済効果について分析する，国民経済レベルにお けるマクロ経済効果として，まず，便益と生産額変化に 着目する（表-3）.

表-3において, 要素賦存量および, 航空輸送サービス 産業における生産性以外の生産技術は，2000年（産業連 
表-3 マクロ経済的効果

\begin{tabular}{|ccc|}
\hline $\begin{array}{c}\text { 航空輸送サービス産業 } \\
\text { TFP 向上率 }\end{array}$ & $\begin{array}{c}\text { 便益 } \\
\text { (EV : 百万円) }\end{array}$ & $\begin{array}{c}\text { 生産額変化 } \\
\text { (百万円) }\end{array}$ \\
\hline $4.8 \%$ & 122,109 & 250,160 \\
\hline
\end{tabular}

関表の時点）から不変と仮定している. すなわち，表-3 の結果は，羽田空港再拡張後の共用時点までに生じる経 済状態変化による影響を一切排除し，発着容量変化によ る影響のみを抽出した結果であることに，留意されたい 便益は年間約1,221億円（プロジェクトライフ30年，社 会的割引率4\%として総便益は約2兆2,000億円）と推定さ れた。一方, 羽田空港再拡張事業は約7,800億円とされ ており，便益が費用を上回ることが示唆される．生産額 について，産業毎の変化額および変化率の相対的な関係 は前節における分析結果とほぼ同様であった。これは, 前節と本節で同一の投入産出構造を仮定したことによる ためである，なお，全産業部門の生産額純変化の合計額 は約2,502億円の増加と推定された.

このように，羽田空港の再拡張により，我が国の経済 活動全般に対して，広く経済効果が伝播することが予想 される.（この点について, Ueda et al. ${ }^{10)}$ は，費用負担の 観点から地域毎の便益帰着を検討している。）羽田空港 が，我が国の国内航空ネットワークの核であることは自 明であり，航空輸送サービス産業の活動において極めて 重要な役割を果たしていることは，疑念の余地がない. 本分析では，羽田空港再拡張による経済的インパクトを， 航空輸送サービス産業のTFP向上，およびそれを通じた 市場間interactionという視点から，定量的推定を行い，羽 田空港の重要性を国民経済的な観点から再確認すること ができた.

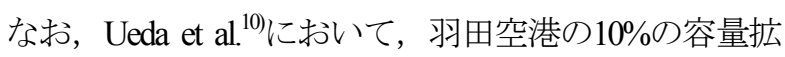
張に対して社会的純便益は年間約330億円と推定されて いる. 本研究では羽田空港再拡張により総スロット数が 25.8万回（2000年実績）から40.7万回に増加した状況を 想定しているが，これは58\%の容量増加に当たる．容量 増加1\%あたりの便益で比べるとUeda et al. ${ }^{10)}$ が約33億円， 本研究が約21億円となる. Ueda et al. ${ }^{10)}$ と本研究ではモデ ル構造や航空企業の行動原理の表現が異なるが，便益の 推定結果は概ね同じオーダーとなっていることが分かる.

本研究の便益推定值の方が小さいことについては，本 研究では航空輸送サービス産業の生産性向上による影響 を，集計的な生産関数を通じた価格 (運賃) 低下に帰着

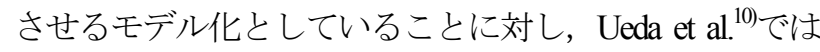
価格低下に加えて便数増に伴う時間短縮などの利便性向 上も含めて便益を計測していることが主な理由として考
えられる。

\section{6. おわりに}

本研究は, Solow残差として表した航空輸送サービス 産業のTFPを, 空港インフラの関数として定式化する手 法を提案し, 我が国では羽田空港の総スロット数を説明 変数とすることにより TFP成長が説明できることを示し た.

また，航空輸送サービス産業のTFP向上を通じて他産 業におよぶ経済効果を, CGEモデルにより推定する手法 を開発し，これまでの羽田空港拡張がもたらしてきた経 済効果および再拡張によってもたらされるであろう経済 効果の推定も行った. その結果, 羽田空港の容量拡大が, 多方面の経済活動を活性化させることが明らかとなり， 羽田空港の容量（あるいは首都圈における空港容量）を 十分に確保することの重要性が示された.

本研究の提案する手法は, 一般均衡体系の中で航空輸 送サービス産業の需要が内生化されている。したがって, 従来から実務的に利用されている費用対効果分析のよう に外生的な需要予測值の入力を必要とせず，総スロット 数の変化のみを外生値として，直接的に便益とその他経 済効果を簡易に推定することが可能である。こうしたフ レームは, 航空分野だけでなく他の交通産業に対しても 適用が可能と考えられる.

本研究では，マクロ経済的な影響に着目するため，日 本全国を一地域として扱ったが，空間的な経済効果の波 及, 地域間の便益帰着比較等を考えるためには, 多地域 モデルへと拡張することが望ましい，今後は，多地域 CGEモデルへの展開，その際の航空輸送サービス産業の モデル化について，発展させることが課題である.

なお，本論文の全ては筆者の個人的見解であり，筆者 の属する組織の見解とは独立なものである. 本研究にお ける一切の誤りや責任は全て筆者に帰寸るものである.

謝辞 : 本研究の成果の一部は, 科学研究費補助金（若手 研究（B）課題番号17760435）による助成を受けたもの である.ここに記して謝意を表したい.

\section{付録：産業連関表からの生産関数パラメータ導出 方法}

産業連関表を列方向に読むと，中間投入と付加価值が 金額ベースで示されている. 寸なわち, 本モデルの変数 名と照合寸ると, 生産関数から生産における中間投入お 
よび生産要素投入需要を導出すると, 各財の中間投入に ついては,

$$
p_{i} x_{i j}=\alpha_{i j} p_{j} x_{j}
$$

付加価值投入については,

$$
\begin{aligned}
& r K_{j}=\alpha_{K j} p_{j} x_{j} \\
& w L_{j}=\alpha_{L j} p_{j} x_{j}
\end{aligned}
$$

という関係が得られる. 円価值単位の考え方に従い，基 準均衡における全ての財・要素価格を1と仮定すれば, 生産関数のシェアパラメータは, 産出額に対する各々の 投入額のシェアとして得られる．また，産業連関表に示 されている金額ベースでの投入需要を量ベースでの投入 需要として扱うことができる. このように得られたシェ アパラメータと投入需要を式(6)の生産関数に代入する ことにより，生産技術パラメータ $\eta_{j}$ が一意に求められ る.

\section{参考文献}

1) Aschauer, D.A.: Is Public Expenditure Productive?, Journal of Monetary Economics, vol.23, pp.177-200, 1989.

2) 三井清, 太田清: 社会資本の生産性と公的金融, 日本評論社,
1995.

3) 江尻良, 奥村誠, 小林潔司: 社会資本の生産性と経済成長: 研 究展望, 土木学会論文集,No.688/IV-53,pp.75-87,2001.

4) 木村達也: トラック輸送業・内航海運業における構造改革, 白桃書房, 2002 .

5) 中島隆信: 日本経済の生産性分析, 日本経済新聞社, 2001 .

6) Gillen, D. and Lall, A.: Developing Measures of Airport Productivity and Performance: An Application of Data Envelopment Analysis, Transportation Research Pt. E, 33(4), 261-273, 1997.

7) Hooper, P. G. and Hensher, D. A.: Measuring Total Factor Productivity of Airports - An Index Number Approach. Transportation Research Pt. E, 33(4), 249-259, 1997.

8) Air Transport Research Society: Airport Benchmarking Report 2003, Air Transport Research Society, 2003.

9) Forsyth, P.: Models of Airport Performance, in Hensher and Button ed. Handbook of Transport Modeling, Elsevier, 2000.

10) Ueda, T., Koike, A., Yamaguchi, K. and Tsuchiya, K.: Spatial Benefit Incident Analysis of Airport Capacity Expansion, Kanafani and Kuroda ed. Global Competition in Transportation Markets: Analysis And Policy Making,pp165-196, 2005.

11) Ishikura, T., Tansei, K. and Sugimura, Y.: An Air Transport Demand Model for Assessing Interaction with Industrial Structure: A Computable General Equilibrium Approach, Journal of the Eastern Asia Society for Transportation Studies, Vol.5, pp437-452, 2003.

12）国土交通省航空局: 東京国際空港再拡張に伴う経済波及効 果調查報告書, 国土交通省航空局, 2003.

\section{CONTRIBUTION TO AIR TRANSPORT PRODUCTIVITY AND NATIONAL ECONOMYBY HANEDA AIRPORT'S CAPACITY EXPANSION}

\section{Tomoki ISHIKURA and Kazuyuki TSUCHIYA}

Capacity expansion of airports, in particular of core airports of the network, can bring the improvement of efficiency of productivity of air transport industry. This paper proposes a methodology that estimates the contribution of airport capacity expansion to improvement of air transport industry's productivity and the economic effect simultaneously. The methodology is developed by the combination of Total Factor Productivity approach and a CGE model. Furthermore this paper practically evaluates the economic contribution of the past Haneda Airport's capacity expansion and estimates the economic effect by reexpansion project of Haneda Airport as a case study. 